PURBawidya: Jurnal Penelitian dan Pengembangan Arkeologi

p-ISSN: 2252-3758, e-ISSN: 2528-3618 — Terakreditasi Kementerian Ristekdikti No. 147/M/KPT/2020 Vol. 9 (2), Juni 2020, pp 149 - 164 a DI: https://doi.org/10.24164/pw.v9i2.358

\title{
KEARIFAN PERMUKIMAN KUNO DOMPU DI KAWASAN SITUS DORO BATA
}

\section{The Wisdom of Ancient Dompu Settlements in The Doro Bata Site Area}

\author{
Nyoman Rema ${ }^{1}$, Ati Rati Hidayah', Bambang Budi Utomo ${ }^{2}$, Sonny C. Wibisono², \\ Syafrudin $^{3}$, Nurhaidah ${ }^{4}$ \\ ${ }^{1)}$ Balai Arkeologi Bali \\ Jalan Raya Sesetan No. 80 Denpasar, Bali \\ E-mail: nyomanrema@yahoo.co.id (corresponding author) \\ atirati83@gmail.com \\ ${ }^{2}$ Pusat Penelitian Arkeologi Nasional \\ Jalan Raya Condet Pejaten No. 4, Jakarta Selatan \\ E-mail: dapuntahyang@yahoo.com \\ E-mail: wibisonny@gmail.com \\ ${ }^{3)}$ Dinas Lingkungan Hidup Kabupaten Dompu \\ Jalan Sultan Hasanuddin No. 49, Kel. Karijawa Dompu, NTB \\ E-mail: syafrudindompu@gmail.com \\ ${ }^{4)}$ Sekretariat Majelis Adat Dana Dompu, Kabupaten Dompu \\ Jalan M. Tajul Arifin, No. 5 Kampung Rato, Kelurahan Karijawa, \\ Kecamatan Dompu, Kabupaten Dompu \\ E-mail: irnurhaidah@gmail.com
}

Naskah diterima: 11 Mei 2020 - Revisi terakhir: 15 Oktober 2020

Disetujui terbit: 15 November 2020 - Tersedia secara online: 30 November 2020

\begin{abstract}
Doro Bata is a site which reflects various layers of culture that once existed in Dompu. Doro Bata is a hill formed in the form of seven terraces, at the peak there is the building foundation structure, as traces of the culture that once were there. This study is to determine the wisdom of the ancient Dompu settlement in the Doro Bata site area. This research data was collected through excavations, interviews, and literature study. The results of this study are in the form of earthenware fragments, ceramic fragments, image of reconstruction of foundation structur, terrace, and local wisdom of space pattern on Doro Bata site area. Analysis of the study proved that the Doro Bata site built with the concept of setlement wisdom that was applied through spatial pattern which was built through the sellection of settlement location by considering aspects of land shape, land surface shape, availability of water sources, and soil fertility. Utilization is divided into open space zone, settlements, farming, cemeteries, and forests.
\end{abstract}

Keywords: wisdom, sattlement, Doro Bata, Leka Dana

\footnotetext{
Abstrak

Doro Bata adalah situs yang mencerminkan berbagai lapisan budaya yang pernah ada di Dompu. Doro Bata adalah bukit yang dibentuk berupa teras berundak sebanyak tujuh teras, di puncaknya terdapat struktur bata, sebagai jejak-jejak budaya yang pernah ada di sana. Penelitian ini bertujuan untuk mengetahui kearifan permukiman kuno Dompu di kawasan Situs Doro Bata. Data penelitian dikumpulkan melalui ekskavasi, wawancara, dan studi pustaka. Hasil penelitian berupa fragmen gerabah, fragmen keramik, gambar
} 
rekonstruksi struktur fondasi, teras berundak, dan kearifan lokal pola ruang kawasan Doro Bata. Analisis penelitian membuktikan bahwa pola ruang Situs Doro Bata dibangun dengan konsep kearifan permukiman yang diaplikasikan melalui pemilihan lokasi permukiman dengan mempertimbangkan aspek bentuk lahan, bentuk permukaan lahan, ketersediaan sumber air, dan kesuburan tanah. Pemanfaatannya terbagi menjadi zona ruang terbuka, permukiman, bercocok tanam, pemakaman, dan hutan.

Kata kunci: kearifan, permukiman, Doro Bata, Leka Dana

\section{PENDAHULUAN}

Dompo awalnya disebut dalam naskah Pararaton, merupakan institusi kesukuan (ncuhi), berubah menjadi kerajaan, kesultanan, selanjutnya sekitar tahun 1940-an menjadi kota kabupaten bagian dari Provinsi Nusa Tenggara Barat dengan sebutan Dompu (Pangeran, 2013). Dompu pernah memegang peranan penting dalam perekonomian Pulau Sumbawa, lazim disebut sebagai lumbung beras Pulau Sumbawa. Kemakmuran Tanah Dompu masa lalu terdengar sampai ke negeri Tiongkok dan negeri-negeri lain di Asia dan Eropa. Hal inilah yang telah mengundang pedagang Tiongkok untuk berdatangan ke Dompu dengan membawa barang-barang keramik untuk ditukar dengan beras dan juga hasil bumi yang lain.

Menurut Abdullah Tajib (1995: 59), pada zaman itu setiap hubungan dengan berbagai suku di Nusantara dari Semenanjung Sumatra hingga Indonesia Timur dan hubungan dengan pihak asing dilakukan melalui pelabuhan kuno di Teluk Cempi. Pelabuhan kuno di Teluk Cempi pada tahun 1420 Masehi disebut sebagai tempat berlabuhnya Indra Kumala dan Indra Zamrut (Saleh, 1985).

Kemakmuran itu sirna ketika meletusnya Gunung Tambora yang membawa bencana besar dan malapetaka. Peristiwa itu dilukiskan mendalam oleh Letnan Owen Philips yang melawat ke Pulau Sumbawa berdasarkan perintah Gubernur Jenderal Inggris Thomas Stamford Raffles yang berkuasa saat itu. Wilayah Dompo dan sebagian Bima mengalami bencana besar, mayat-mayat bergelimpangan di pinggir jalan, rumahrumah hancur, penduduk yang masih hidup menderita kelaparan (Raffles, 2014).

Awak kapal penjelajah perusahaan Hindia Timur Inggris bernama Benares pada 18 April 1815 untuk pertama kalinya melihat garis Pantai Sumbawa yang rusak. Benares harus melintasi kumpulan batu apung yang bercampur dengan pohon-pohon tumbang untuk mencapai perairan dalam di Teluk Bima pada pagi berikutnya. Selanjutnya, tulis Benares, seluruh Pulau Sumbawa telah berubah hampir tidak dapat dikenali (Saleh, 1985). Letusan ini juga mengakibatkan istana Dompu yang semula berada di Bata karena tertimbun abu dan tidak dapat didiami, dipindahkan ke sebelah utara sungai, tepatnya di area Masjid Agung Baiturrahman sekarang (Sjamsuddin, 2015: 86-87).

Kawasan pertanian Dompu sebagian telah menjadi savana akibat tertimbun material piroklastik yang sangat tebal jika diamati dari garis pantai, menutupi lapisan tanah yang subur. Banyak sekali mata air yang berkurang debitnya, aliran sungai menjadi kecil akibat perubahan cuaca dan aktivitas yang menimbulkan kerusakan 
lingkungan, termasuk gangguan sampah yang melintas di area terlindungi, yang menghendaki adanya konservasi.

Berbagai peristiwa tersebut mendorong para peneliti untuk mengetahui peradaban Pulau Sumbawa dan Dompu khususnya. Penelitian tersebut berhasil mengungkapkan bahwa kebudayaan Kepulauan Sumbawa telah berlangsung dari masa prasejarah dan terus mengalami perkembangan hingga masa Hindu-Buddha, Islam, dan zaman modern. Pusat-pusat aktivitas masyarakat masih berada dekat dengan sumber air, kondisi sekarang pun masih serupa, jika dilihat dari foto udara. Perkembangan tersebut dibuktikan oleh penelitian yang pernah dilakukan oleh para ahli, diantaranya oleh Chambert Loir dan Djafar yang menguraikan bahwa terdapatnya tinggalan berupa dua relief arca, yaitu arca Ganesa dan Buddha Amitaba, lingga, dan beberapa pahatan relief stupa pada dinding gua yang ditemukan di dekat Batupahat, Bima, yang oleh penduduk sekitar disebut Wadupaa, diduga dari abad ke-6 - 7 Masehi (Chambert-Loir, 1985; Djafar, 2012; Utomo, 2018).

Balai Pelestarian Cagar Budaya Bali (BPCB Bali) dalam situsnya yang diungggah pada 24 April 2019, telah mengkaji sejarah Dompu berikut dengan struktur ruang rumah ruka wanga. Kajian sejarah yang bersumber dari ceritra rakyat masyarakat Dompu menerangkan bahwa nenek moyang mereka berasal dari suatu negeri yang disebut Pulau Sumatra sekarang (Artanegara, 2019). Berikutnya M.M. Soekarto K Atmodjo (1994: 3) menguraikan temuan prasasti wadu tunti (batu tulis) yang dipahatkan pada batu besar, di daerah Bolo, Bima. Prasasti ini dipahatkan dengan aksara Jawa Kuno dan berasal dari masa sekitar 1350/1400 Masehi atau sezaman dengan masa pemerintahan Raja Hayam Wuruk dari Kerajaan Majapahit, menyebut seorang tokoh raja bernama Sang Āji Sapalu yang telah hilang atau moksa setelah terjadi peperangan bhalang geni atau lempar api. Pada sisi lain batu prasasti ini, terdapat pula pahatan berupa relief yang menggambarkan adegan berupa empat tokoh kedewataan dengan seekor harimau dan tokoh di tengah yang menggambarkan Dewa Siwa. Penelitian tersebut sangat berguna sebagai bukti bahwa pengaruh Majapahit telah sampai ke Pulau Sumbawa dan telah berhasil mengalahkan rajanya yang disebut Aji Sapalu.

Slamet Muljana (2006: 161) menguraikan mengenai pulau-pulau di sebelah timur Pulau Jawa, pertama-tama disebut Pulau Bali, yang ditundukkan pada tahun 1343 Masehi, berikut Pulau Lombok atau Gurun, yang dihuni oleh suku Sasak. Dompo (Dompu sekarang) yang terletak di Pulau Sumbawa, menurut Nagarakretagama pupuh 72/2-3 dan Pararaton, ditundukkan oleh tentara Majapahit di bawah pimpinan Mpu Nala pada tahun 1357 Masehi. Pengaruh Majapahit di Pulau Sumbawa di antaranya Bima dan Dompu meninggalkan berbagai artefak yang dapat dijumpai hingga saat ini, di antaranya berupa yoni, nandi, keris pusaka, dan bangunan suci (Susetyo, 2014).

Penelitian di Kecamatan Hu'u, Dompu yang dilaksanakan oleh Ayu Kusumawati (2010: 513), Purusa Mahawiranata (2004: 4) serta I Nyoman Rema dan Syafrudin (2019: 25-38) menemukan berbagai tinggalan, seperti kubur duduk, fragmen gerabah, batu penutup kubur, dan tahta batu. Hal yang menunjukkan perkembangan selanjutnya di Hu'u ialah di Situs So Langgodu. A.A. Gde Bagus (2014: 92) 
menemukan pecahan gerabah dan keramik sebagai indikasi adanya permukiman di situs tersebut. Penelitian lainnya di Situs Ta'a, Kecamatan Kempo ditemukan keramik, uang kepeng, dan benda perunggu yang digunakan sebagai bekal kubur karena memiliki konteks dengan temuan rangka manusia (Ambarawati, 2010: 103). Penelitian juga dilaksanakan di kawasan Gunung Tambora dengan temuan berbagai artefak permukiman, seperti rumah yang terarangkan, peralatan rumah tangga, bandul pancing, dan manik-manik tanah liat yang terkubur akibat letusan gunung ini. Dampak letusan juga sangat luas, mengubur peradaban Dompu yang terus dicari jejaknya (Haribuana, 2017: 20).

Penelitian terdahulu di Kecamatan Dompu pernah dilakukan di Situs Doro Bata yang terletak di sebelah selatan Sungai Laju dan telah berhasil mengungkap keberadaan Situs Doro Bata yang merupakan salah satu situs penting karena menjadi salah satu cikal-bakal Kabupaten Dompu, dengan tinggalan berupa struktur teras berundak (Kusumawati, 2007: 112). Tempat diselenggarakannya ritual pemujaan leluhur pada masa Ncuhi dan para Dewa pada masa pengaruh Majapahit di tanah Dompu mulai tahun 1357 Masehi hingga akhirnya tahun 1545 Masehi berubah menjadi istana Bata yang dibangun oleh sultan pertama Dompu yang bergelar Sultan Syamsudin dan ditinggalkan pada tahun 1815 akibat letusan Gunung Tambora (Ambarawati, 2010; Rema, Juliawati, \& Prihatmoko, 2018; Rema \& Sumerata, 2016; Suantika, Ambarawati, \& Mahaviranata, 1994; Sumerata, 2014) Penelitian tersebut belum ada yang secara spesifik mengulas kearifan permukiman kuno Dompu di Kawasan Situs Doro Bata sehingga relevan untuk ditulis. Penelitian ini mengangkat kearifan permukiman kuno yang ditemukan di kawasan Situs Doro Bata. Penelitian ini bertujuan untuk mengetahui kearifan permukiman kuno yang diterapkan di kawasan Situs Doro Bata. Penelitian ini diharapkan dapat menemukan budaya hunian dan konsep keruangan di kawasan situs Doro Bata.

Penelitian kearifan permukiman berkaitan dengan adaptasi manusia terhadap lingkungan geografis tertentu. Ada bagian inti dari sistem budaya yang sangat responsif terhadap adaptasi ekologis. Oleh karena itu, berbagai proses penyesuaian terhadap tekanan ekologis, secara langsung akan dapat memengaruhi unsur-unsur inti dari suatu struktur sosial. Agar tetap produktif, pada suatu perubahan kebudayaan yang diakibatkan oleh faktor ekologi harus dilakukan pengaturan kembali. Berbagai upaya pengaturan kembali tersebut akan berpengaruh pula terhadap struktur sosial mereka (Steward, 1963: 37).

Julian H. Steward (1963: 40) juga menegaskan bahwa dalam kultur ekologi (1) ada hubungan antara teknologi yang dipergunakan dengan keadaan suatu lingkungan tertentu, (2) pola-pola kelakuan dalam rangka mengeksploitasi suatu daerah, erat kaitannya dengan suatu bentuk teknologi yang diciptakan, dan (3) pola-pola kelakuan dalam rangka itu akan berpengaruh terhadap berbagai aspek dari kebudayaannya. Salah satu aspek kebudayaan adalah nilai dan tinggalan artefak yang akan diobservasi, yang memiliki bentuk/tipe, kemudian dibuatkan klasifikasi dan kategori dari tipe tersebut sehingga akan dilihat keragaman dan keseragaman dari suatu objek temuan yang 
kemudian dilanjutkan dengan memberikan penjelasan objek temuan tersebut (Iswati, 2003). Dicontohkan oleh (1982) bahwa tipologi ditinjau dari objek bangunan yang terbagi tiga hal pokok, yaitu site (tapak) bangunan, form (bentuk) bangunan, dan organisasi bagian-bagian bangunan (Purwasito, 2002: 268). Temuan-temuan tersebut akan menghasilkan sumber-sumber ketimuran yang pada dasarnya adalah penemuan kembali pola-pola keruangan yang diwariskan nenek moyang yang berlangsung dari masa ncuhi hingga Islam di Dompu.

Pola keruangan yang dimaksud adalah kearifan permukiman kuno Dompu di kawasan situs Doro Bata di Lingkungan Sambi Tangga, Kelurahan Kandai Satu, Kecamatan Dompu, Kabupaten Dompu, Provinsi Nusa Tenggara Barat. Secara astronomi situs berada pada koordinat $8^{\circ} 47^{\prime} 59^{\prime \prime}$ Lintang Selatan dan $118^{\circ} 23^{\prime} 36^{\prime \prime}$ Bujur Timur (Gambar 1). Penelitian ini merupakan penelitian kualitatif dengan pendekatan lanskap untuk merekonstruksi pola ruang yang diadaptasi sebagai permukiman, berdasarkan pengamatan terhadap objek penelitian yang dipadukan dengan kearifan lokal permukiman Dompu. Sumber data penelitian terdiri atas sumber primer dan sekunder. Sumber primer dikumpulkan melalui observasi lapangan, yakni melalui ekskavasi, survei, dan wawancara, sedangkan sumber sekunder melalui penelusuran pustaka yang relevan. Setelah data terkumpul, kemudian data dianalisis dengan tahapan reduksi data, yaitu pemilihan, penyederhanaan, dan transformasi data kasar; dilanjutkan dengan merangkai dan menyusun informasi dan interpretasi, mencari makna di balik fakta sehingga gejala yang diamati dapat memiliki nilai dalam kehidupan masyarakat luas. Kemudian dilanjutkan dengan menarik kesimpulan.

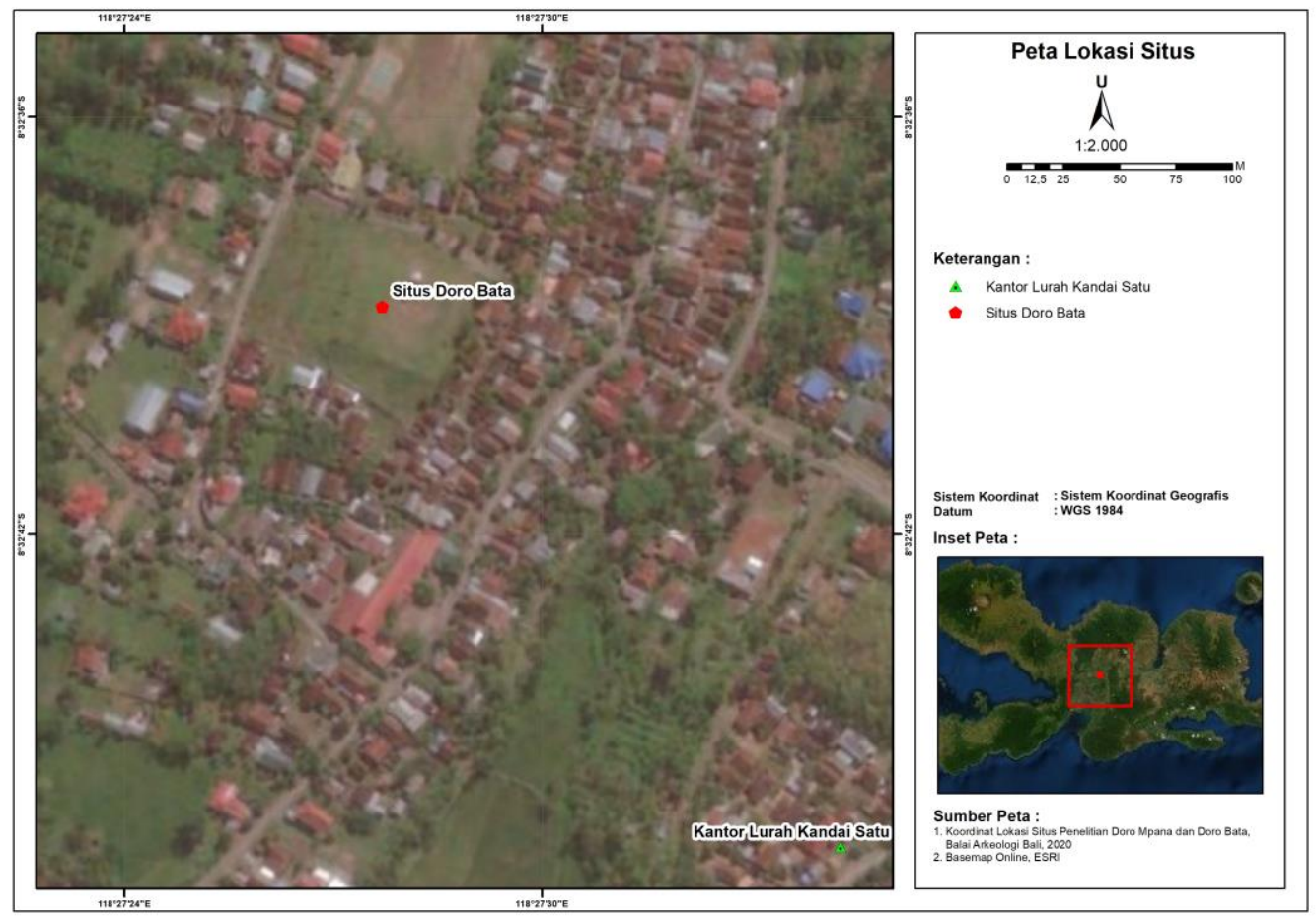

Gambar 1. Peta lokasi penelitian situs Doro Bata di Kabupaten Dompu Nusa Tenggara Barat (Sumber: Dokumen Balai Arkeologi Bali). 


\section{HASIL DAN PEMBAHASAN}

Doro Bata dikenal sebagai situs yang mengandung tinggalan budaya masa lampau berupa bata dalam bentuk struktur maupun lepasan. Sejak awal tahun 1970-an, tim kecil dari Lembaga Purbakala dan Peninggalan Nasional (LPPN, sekarang Pusat Penelitian Arkeologi Nasional) telah melakukan survei ke desa tersebut. Survei yang agak menyeluruh ke Pulau Sumbawa dipimpin oleh Hasan Muarif Ambary pada tahun 1974. Pada waktu itu pengamatan lebih mencermati pada tinggalan budaya masa kerajaan Islam di Sumbawa, seperti makam-makam dengan aneka macam bentuk batu nisannya. Perhatian terhadap tinggalan budaya masa lampau di situs Doro Bata lebih ditingkatkan lagi manakala situs tersebut mendapat perhatian lebih dari masyarakat di Dompu karena di puncaknya terdapat lubang di antara struktur bata yang tersisa, tempat menancapkan batu berdiri dan melaksanakan ritual pemujaan kekuatan alam dan leluhur toho ra dore. Selain itu, oleh penduduk setempat Doro Bata dianggap sebagai tempat yang keramat (Gambar 2) (Rema et al., 2019: 94).

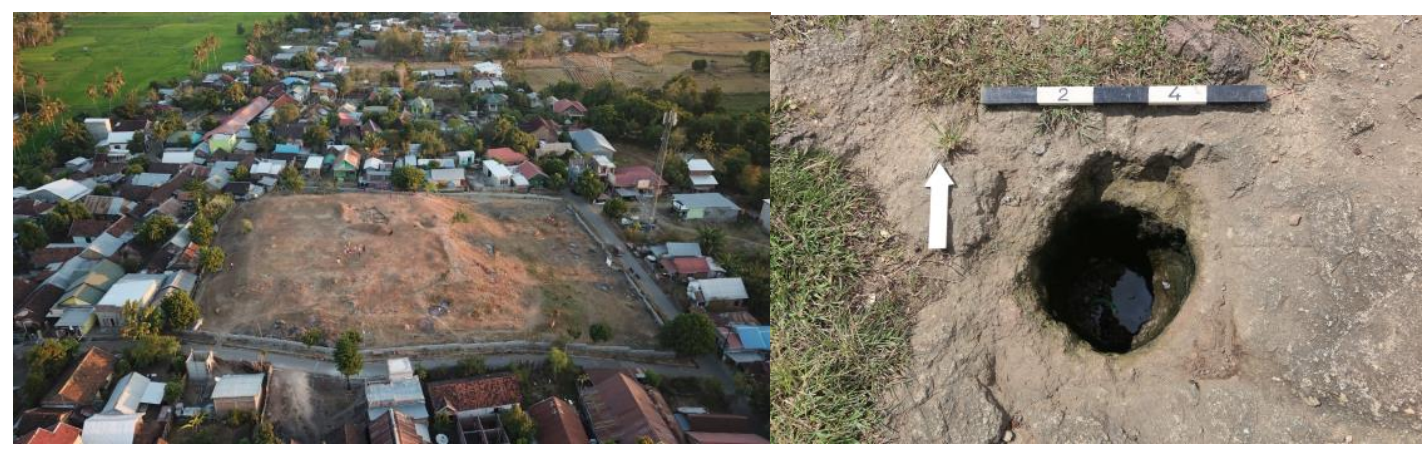

Gambar 2. Situs Doro Bata dan lubang keramat di puncak Doro Bata (Sumber: Dokumen Balai Arkeologi Bali, 2017, 2019).

Konteks Doro Bata dengan lingkungan sekitarnya merupakan bukit kecil tertinggi pada dataran yang dikelilingi rangkaian perbukitan. Di sebelah timur laututara-barat daya mengalir Sungai Nae/Laju yang kemudian bermuara di Teluk Cempi di pantai selatan (Gambar 3). Keadaan lingkungan ini seperti layaknya Candi Borobudur yang bertumpu pada sebuah bukit kecil di tengah dataran lembah Sungai Progo yang dikelilingi rangkaian perbukitan Menoreh. Jika melihat perbandingan itu, dahulu di puncaknya pernah berdiri objek pemujaan. Objek pemujaan berupa bangunan suci ini berfungsi paling tidak setelah digantikannya institusi kerajaan yang mendapat pengaruh budaya India (agama Hindu-Buddha), ke institusi kerajaan yang beragama Islam (Rema et al., 2019). 


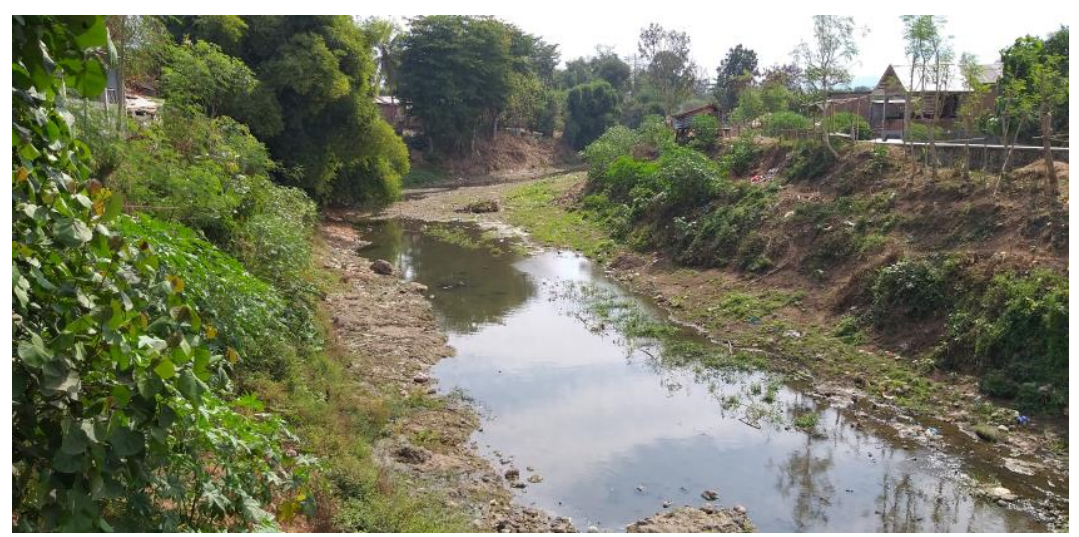

Gambar 3. Sungai Nae/Laju (Sumber: Dokumen Balai Arkeologi Bali, 2019).

Secara topografis situs ini terletak pada bukit kecil yang tingginya sekitar10 meter dari permukaan tanah sekitarnya. Bukit kecil ini berbentuk seperti batok kelapa, sebagaimana Gunung Batok di Kaldera Bromo. Bukit dibentuk secara sengaja berdenah bujur sangkar, berukuran 54 x 54 meter membujur arah barat-timur dan utara-selatan. Makin ke atas sisi-sisinya makin kecil sehingga berbentuk teras berundak. Setiap teras dibatasi dengan batu kali, dan di atas batu dilapis dengan bata, pada setiap sudut dipasang batu besar, yang diperkirakan sebagai penanda batas, dan penegas area suci. Tangga sebagai pintu keluar terdapat pada bagian sisi barat (Gambar 4 dan 5).

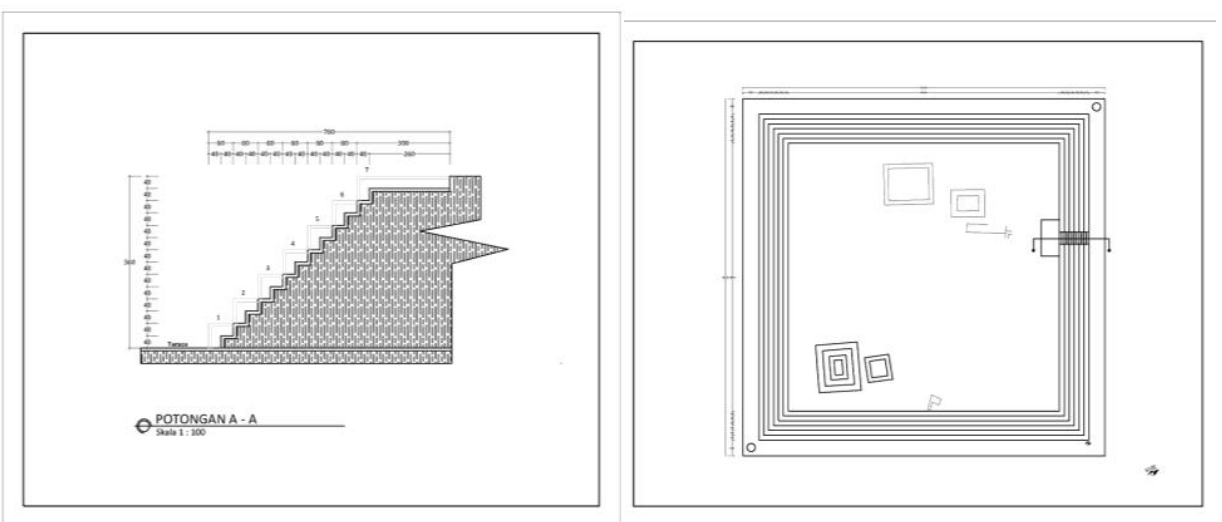

Gambar 4. Rekonstruksi teras berundak, struktur fondasi tampak atas, dan potongan teras berundak Doro Bata tampak samping (Sumber: Dokumen Balai Arkeologi Bali, 2019).

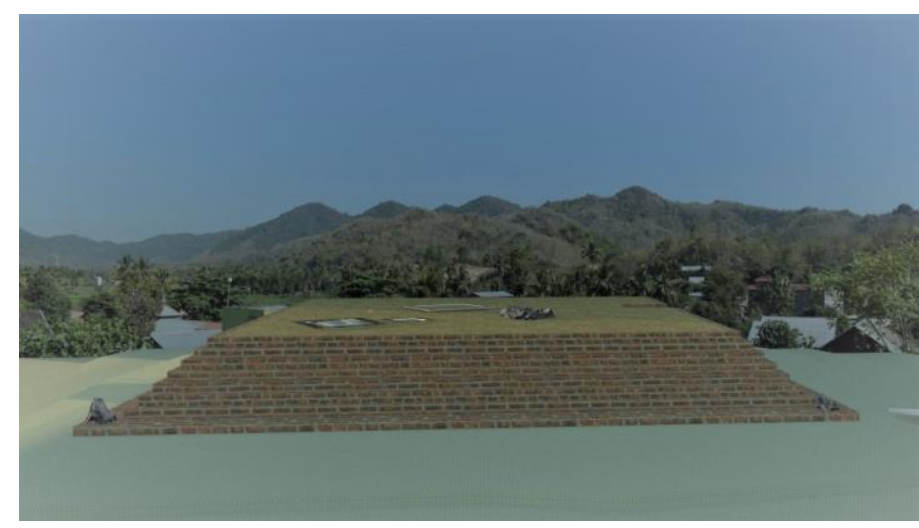

Gambar 5. Rekostruksi teras berundak Doro Bata (Sumber: Dokumen Balai Arkeologi Bali, 2019). 
Berdasarkan hasil penelitian arkeologi yang telah dilakukan sebanyak 17 tahap penelitian, pada puncak teras berundak Doro Bata yang luasnya $1551,84 \mathrm{~m}^{2}$ terdapat sekurang-kurangnya empat bangunan yang terpisah antara satu dan lainnya. Ini menunjukkan sebuah kompleks bangunan yang berdiri di puncak bukit kecil. Selain struktur fondasi bata, ditemukan pula fragmen logam, fragmen gerabah berslip merah dan tanpa slip merah, uang kepeng Cina dari Dinasti Qing abad ke-18 - 19 Masehi, fragmen keramik asing dari Dinasti Song abad ke-12 - 13 Masehi, Dinasti Ming abad ke-14 - 15 Masehi hingga Dinasti Qing abad ke-18 - 19 Masehi. Keramik yang terbanyak ditemukan adalah dari Dinasti Ming. Selain dari Cina, juga terdapat keramik Thailand dari Sawankhalok abad ke-14 - 16 Masehi dan dari Vietnam abad ke-14 - 16 Masehi (Rema et al., 2019: 89, 95).

Hal menarik dari temuan indikator permukiman adalah pecahan-pecahan tembikar yang mempunyai ciri khas Majapahit. Tembikar Majapahit berwarna merah, mempunyai ketebalan sekitar $1-2$ milimeter, dan bertemper halus. Jika melihat bentuk pecahan dan tempernya, fragmen tembikar tersebut berasal dari bentuk kendi atau wadah untuk menampung air, seperti mangkuk. Kendi Majapahit banyak ditemukan di Trowulan dan situs-situs lain di daerah Jawa Timur. Pada masa Kerajaan Majapahit (abad ke-13 - 14) persebaran kendi ini di Nusantara cukup luas hingga di daerah Jambi, Palembang, Ketapang (Kalimantan Barat), dan Bantaeng (Sulawesi Selatan). Berdasarkan temuan kendi Majapahit, diduga pengaruh Majapahit di Dompu sudah ada (Rema et al., 2019: 98).

Keberadaan kendi atau wadah tipe Majapahit di sekitar puncak Doro Bata kemungkinan berfungsi pada waktu upacara keagamaan. Kendi berfungsi sebagai tempat air suci yang dibawa oleh pendeta ketika upacara berlangsung. Bentuk kendi sama seperti yang ditemukan di daerah-daerah yang diduga merupakan bekas lokasi pemukiman kuno Majapahit sebagaimana disebut terdahulu. Hal ini sejalan dengan informasi dari tokoh masyarakat dan budayawan ataupun sejarawan bahwa puncak bukit ini, yaitu pada lubang, dijadikan sebagai tempat pemujaan dan ritual toho ra dore. Mengenai struktur bata yang ditemukan secara horizontal di puncak Doro Bata, diduga kuat berasal dari masa jauh sebelum Kerajaan Dompu, yaitu sezaman dengan Majapahit (abad ke-15 Masehi). Dugaan ini didasarkan pada teknik melekatkan bata, yaitu dengan teknik gosok tanpa menggunakan spesi semen (Gambar 6).

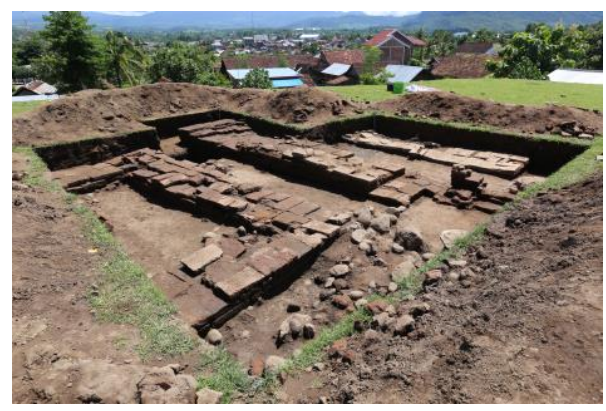

Gambar 6. Temuan struktur fondasi bangunan di puncak Doro Bata (Sumber: Dokumen Balai Arkeologi Bali, 2017). 
Setelah Islam masuk, beberapa struktur bata tersebut kemudian ditimbun dan di atasnya didirikan Asi/Istana Kesultanan Dompu, dengan konstruksi dari kayu berupa beberapa uma panggu bertiang sembilan yang digabung menjadi satu. Penimbunan tersebut berkaitan dengan beberapa sistem dan tata nilai terkait kepercayaan yang berbeda. Pascaletusan Gunung Tambora tahun 1815, Asi/Istana yang ada di atas Doro Bata hancur karena dampak letusan, kemudian dipindahkan ke sebelah utara Sori Na,e/Laju, dan didirikan dengan konstruksi yang sama, yaitu dari kayu (Rema et al., 2019: 69-70).

Sebagaimana telah dijelaskan, Doro Bata dibangun pada bukit yang sekitarnya juga dikelilingi oleh rangkaian perbukitan yang rimbun dengan pepohonan yang dijaga sebagai kawasan hutan. Secara umum, pola ruang kawasan Doro Bata dan sekitarnya terbagi menjadi beberapa fungsi, yang menjadi bagian dari pusat dan subpusat kawasan. Fungsi kawasan ini ditentukan oleh jenis kegiatan yang dilaksanakan, skala kepentingan, tempat diselenggarakan kegiatan atau aktivitas, serta ukuran ruang yang dipergunakan. Istana merupakan pusat kawasan, dengan fungsi utama sebagai pusat pemerintahan dan tempat tinggal raja/sultan beserta keluarganya. Subpusat kawasan adalah lapangan atau ruang terbuka, area permukiman, sungai, areal bercocok tanam, makam, mata air, dan areal hutan.

Setiap bangunan yang didirikan harus searah dengan gunung. Pengaturan arah bangunan ini merupakan sebuah respons terhadap keyakinan dan kepercayaan masyarakat Dompu tentang keberadaan gunung yang memberikan pengaruh terhadap keberlangsungan hidup masyarakat. Nilai yang diyakini masyarakat Dompu pada masa itu adalah bahwa gunung merupakan salah satu sumber kehidupan bagi masyarakat, tempat tersedianya kebutuhan hidup, tempat bersemayamnya arwah leluhur, dan dekat dengan langit. Berdasarkan keyakinan masyarakat, apabila bangunan tempat tinggal berlawanan dengan arah gunung atau arahnya menusuk gunung, keberlangsungan hidup masyarakat akan terganggu, keluarga yang tinggal dalam bangunan tersebut akan sering sakit, rumah tangga tidak tentram, sering bertengkar, dapat mengakibatkan kemiskinan, rezeki yang seret, tidak dapat berinteraksi dengan baik dengan tetangga, dapat menyebabkan kematian bagi penghuni bangunan dan lain-lain (Rema et al., 2019: 76).

Jika melihat struktur fondasi bangunan dan arah hadap Situs Doro Bata, berdasarkan hasil penelitian hingga tahun 2019, ditemukan adanya beberapa struktur bata yang mengarah ke utara-selatan, tidak berlawanan dengan arah rangkaian gunung yang berada di sebelah timur. Dapat dikatakan bahwa konsep wati tuba doro diaplikasikan pada proses pembangunan Doro Bata. Jika menggunakan pendekatan ilmiah dan kesehatan, makna dan pengaruh secara spesifik dari konsep wati tuba doro ini terhadap bangunan yang ada, dengan melihat arah hadap bangunan, kemudian dikaitkan dengan bentuk serta ruangan yang ada pada bangunan dengan konstruksi kayu/rumah panggung, dapat disimpulkan bahwa ketika pagi hari sinar matahari sempurna masuk ke dalam seluruh ruangan dalam bangunan sehingga penyinaran dan suhu di dalam semua ruangan akan terjaga. 
Demikian halnya dengan sirkulasi udara, pergantian antara yang masuk dan keluar ruangan terjadi dengan baik, maka akan memberikan pengaruh pada kondisi ruangan yang tidak pengap, segar dan sejuk sehingga berpengaruh pada kesehatan dan daya tahan tubuh yang baik bagi penghuninya. Ketika pemilik bangunan memiliki kesehatan yang baik, mereka dapat menjalankan aktivitasnya dengan prima, beristirahat dengan tenang, bekerja dengan maksimal, membina komunikasi dan interaksi yang baik antara sesama anggota keluarga dan tetangga, serta dapat menjaga kebugaran, dan sebagainya.

Harapannya adalah hal itu membawa dampak pada terhindarnya orang-orang dari sakit berkepanjangan, termasuk pandemi, terhindar dari rasa malas, jauh dari emosi yang tidak stabil, terhindar dari pertengkaran dalam keluarga, kemauan untuk bekerja keras lebih tinggi, kemauan untuk membina tali silaturahim dengan keluarga dan masyarakat sehingga kehidupan dalam rumah tangga dan bermasyarakat terbina dan terjaga dengan baik.

Kearifan permukiman ini terbentuk karena adanya pengaruh dari sistem dan tata nilai budaya yang dijalankan dan dilaksanakan oleh masyarakatnya sejak masa kepemimpinan ketua suku di Dompu yang disebut ncuhi, masa kerajaan, masa kesultanan, hingga sekarang. Sistem dan tata nilai ini berbetuk keyakinan yang berkaitan dengan hubungan antara perilaku masyarakat dengan lingkungan alam. Berdasarkan hubungan ini lahir suatu aktualisasi pada penandaan-penandaan tertentu terhadap lingkungan berdasarkan jenis perilaku yang berkembang, selanjutnya dilakukan penataan dan pengaturan menurut nilai-nilai yang diyakini tersebut, yang kesemuanya terwujud dalam bentukan fisik yang nyata.

Pola ruang makro kawasan Doro Bata memiliki konsep yang disebut leka dana. Leka dana adalah sebuah konsep pemilihan lahan yang digunakan untuk membangun suatu kawasan permukiman berdasarkan pertimbangan kondisi lingkungan, daya dukung, dan daya tampung alam, yaitu menekankan pada kondisi fisik dasar untuk memperoleh kesesuaian lahan. Keadaan tanah dan batuan yang ada pada suatu lahan berpengaruh terhadap kemudahan pengolahannya. Struktur tanah yang dipilih untuk kawasan pemukiman mempunyai struktur tanah yang baik dan kuat, bukan kategori tanah dengan struktur liat. Areal tanah yang mempunyai kesuburan tinggi dipilih sebagai areal pertanian. Selain dari jenis tanah, lokasi atau jenis lahan yang ada juga menjadi pertimbangan penting yang dipilih oleh masyarakat dalam mendirikan tempat tinggal. Aspek hidrologi merupakan salah satu aspek penting yang dipertimbangkan dalam memilih suatu kawasan untuk kegiatan pembangunan. Pada satu sisi, selain keberadaan untuk memenuhi kebutuhan hidup bagi masyarakat, air juga digunakan untuk perlengkapan ritual keagamaan serta menjadi pertimbangan dalam pelaksanaan kehidupan sehari-hari, sedangkan dalam jumlah yang banyak, air juga akan memberikan pengaruh terhadap kegiatan pertanian dan kegiatan lainnya (Syafrudin, 2016: 80).

Ketersediaan dan lokasi sumber air yang dekat untuk kebutuhan hidup seharihari ataupun pelaksanaan kegiatan lainnya menjadi pertimbangan dalam menentukan lokasi kawasan permukiman. Untuk sumber-sumber air, seperti mata air dan sungai, 
terdapat ruang karama, yaitu ruang khusus yang secara fungsi sama dengan ruang imajiner, ruang ini mempunyai perlakuan khusus di sekeliling atau di pinggirnya, yaitu dilindungi dan dipertahankan untuk tidak dipergunakan dan dimanfaatkan bagi kegiatan. Jika ruang ini diganggu atau dirusak, kesehatan dapat terganggu, kemalangan, juga mengakibatkan kematian. Untuk mempertegas dan memperjelas ruang imajiner ini, biasanya ruang ini ditanami pohon dan keberadaan pohon-pohon tersebut dilindungi, yang diperuntukan dan difungsikan sebagai areal konservasi untuk menjaga ketersediaan sumber air tersebut (Syafrudin, 2016: 80-81).

Pada masa kepemimpinan ketua suku di Dompu yang disebut ncuhi yang menganut nilai animisme, tempat-tempat yang tinggi seperti bukit dan gunung dipilih oleh masyarakat sebagai tempat untuk pemujaan arwah leluhur. Tempat tinggi diyakini sebagai tempat bersemayamnya arwah leluhur, dekat dengan langit, terlindung dari gangguan, baik binatang buas, serangan musuh, terjaga dari aktivitas masyarakat, serta dapat mengamati segala arah. Kawasan Doro Bata sangat tepat dipilih sebagai tempat pemujaan, mengingat kondisi awalanya merupakan bukit yang dikelilingi oleh areal datar yang luas, terdapat jajaran gunung dan bukit yang membentang, seperti sebuah benteng alam. Keberadaan bukit sangat sesuai dipilih untuk digunakan dalam mendirikan bangunan dengan fungsi khusus/istimewa, yang memiliki nilai istimewa, terjaga, dan terlindungi.

Kawasan dengan topografi cenderung datar sampai bergelombang dipilih untuk areal rasa (permukiman) dengan segala aktivitas dan ruang pendukungnya. Areal untuk bercocok tanam tolo (sawah) juga berada dalam kawasan datar yang dekat dengan sumber air, seperti sungai sebagai sumber pengairan, juga mata air yang dipergunakan untuk memenuhi kehidupan sehari-hari serta untuk kebutuhan ritual khusus. Kawasan bergelombang diutamakan sebagai kawasan nggaro (kebun), oma (ladang), serta areal untuk menggembalakan hewan ternak.

Berdasarkan pertimbangan kondisi lahan ini, diputuskan bahwa lahan subur digunakan sebagai areal pertanian karena akan berpengaruh pada melimpahnya produksi atau hasil pertanian sehingga akan terus dipertahankan dan dijaga untuk tidak dibangun atau dipergunakan sebagai lokasi permukiman. Areal yang kurang subur biasanya difungsikan untuk kegiatan mendirikan bangunan, ruang terbuka, lokasi berkebun atau berladang, tempat melepas hewan ternak, atau juga sebagai areal hutan. Pola ruang berdasarkan konsep leka dana pada masa animisme atau ncuhi dan berlanjut pada masa kerajaan, Doro Bata masih digunakan sebagai tempat pemujaan.

Pada masa kesultanan, terjadi perubahan sistem keyakinan, yaitu pemujaan kepada arwah leluhur atau ritual toho ra dore tidak diperkenankan lagi dilaksanakan oleh masyarakat. Akan tetapi, perlakuan terhadap beberapa ruang yang ada pada masa animisme dan pada kerajaan, seperti mata air dan sungai masih diberlakukan untuk melindungi kelestarian sumber mata air dan keberlanjutan ketersedian air. Konsep leka dana masih dipergunakan dan menjadi bahan pertimbangan dalam pengembangan kawasan. Berdasarkan konsep leka dana tersebut, kawasan Doro Bata dan sekitarnya dibagi menjadi beberapa zona pemanfaatan ruang berdasarkan pendekatan topografi, 
geologi, hidrologi dan kesuburan (Rema et al., 2019: 68). Beberapa zona yang ditemukan di Kawasan Situs Doro Bata adalah sebagai berikut.

\section{Zona Ruang Terbuka}

Zona ruang terbuka adalah zona yang dipergunakan sebagai tempat untuk berlangsung kegiatan yang melibatkan orang banyak, bersifat terbuka atau tidak ada batasan fisik, dengan bentuk seperti halaman atau lapangan. Bagian utara Doro Bata dijadikan sebagai ruang terbuka atau lapangan, sedangkan di bagian atas Doro Bata, bagian depan/bagian barat terdapat halaman yang luas, sebagai ruang terbuka.

\section{Zona Permukiman (Uma ra Baru)}

Zona ini digunakan untuk mendirikan bangunan tempat tinggal dan bangunan sosial lainnya pada masa lalu. Indikator sisa permukiman kelompok masyarakat pendukung Doro Bata dapat diketahui dari pecahan-pecahan tembikar dan keramik yang merupakan sisa barang-barang keperluan sehari-hari. Di dataran puncak Doro Bata memang ditemukan pecahan-pecahan tembikar dan keramik, tetapi populasinya tidak signifikan untuk dikatakan sisa permukiman. Survei yang dilakukan di Situs Doro Mpana yang lokasinya di sebelah tenggara Situs Doro Bata adalah ditemukan jejak permukiman berupa keramik dari berbagai dinasti, seperti Song hingga Qing, abad ke10-19, yang diperkuat juga dengan analisis carbon dating atas temuan arang yang berasosiasi dengan temuan rangka manusia yang menghasilkan pertanggalan sekitar abad ke-14 (Juliawati et al., 2019: 15).Temuan ini mencerminkan adanya aktivitas ekonomi masyarakat berlangsung dari masa sebelum Kesultanan Dompu hingga masa Kesultanan Dompu.

Hasil survei yang penting di situs ini menguatkan dugaan sebagai permukiman adalah adanya sungai di kaki bukit dengan berbagai sumber mata air sepanjang musim tidak pernah kering. Temuan gerabah bervariasi yang tersingkap pada lereng bukit, temuan bata berukuran besar yang setipe dengan bata Doro Bata juga memperkuat dugaan tersebut. Lurah Kandai I juga memberikan penjelasan bahwa pada masa lalu areal ini dikelilingi oleh benteng berupa struktur batu, tetapi kini telah terganggu, ketika dilakukan observasi masih dapat dilihat jejaknya. Berdasarkan bukti-bukti tersebut, dapat diduga bahwa di daerah inilah salah satu pemukiman masa lampau Doro Bata berada, selain di Woro Kali, Sambi Tangga. Permukiman pendukung lainnya masih terus dicari sehingga nantinya dapat dipetakan keberadaannya.

\section{Zona Bercocok Tanam (Kanggihi Kanggama)}

Sebelah Barat dan Selatan Doro Bata sampai saat ini masih dapat diamati bentangan lahan pertanian yang subur, kondisi lahannya yang datar, memiliki sumber air dari Sungai Laju, Mboko, Silo dan lain-lain yang airnya cukup deras sebagai sumber pengairan. Lahan yang subur ini ditunjang dengan sistem tata kelola pertanian yang telah teratur, yang diwariskan secara turun-temurun, berupa kearifan permukiman masyarakat yang unggul disebut leka dana (Syafrudin, 2016: 77, 78). Konsep semacam 
ini sukses membawa Dompu pada masa lalu sebagai daerah yang sejahtera dan surplus beras (Saleh, 1985).

\section{Zona Pemakaman (Rade)}

Area pemakaman masa lalu Dompu di kawasan Doro Bata, termasuk Bangsawan Dompu tampaknya masih melanjutkan tradisi prasejarah dengan budaya megalitik. Simpulan ini cukup beralasan, mengingat penguburan pada masa kuno Dompu menggunakan batu besar sebagai penutup kubur dan penguburan dilakukan di puncak bukit. Sebagaimana diamati di Doro Mpana, terdapat makam sultan pertama Dompu, yaitu Sultan Syamsudin dan beberapa makam lain.

\section{Zona Hutan (Doro ra Wuba)}

Area gunung, bukit, lahan bergelombang, pinggiran sungai yang ada di kawasan Doro Bata ditumbuhi ditanami pepohonan besar yang terus dijaga dan dipertahankan dalam rangkaian konservasi lingkungan dalam mempertahankan sumber air. Kearifan permukiman ini masih berlanjut digunakan oleh masyarakat Dompu hingga saat ini. Perbukitan dan pinggiran sungai masih tampak rimbun dengan berbagai pepohonan yang terus dijaga untuk daur hidrologi dan mencegah longsor ataupun erosi. Ketika membuka lahan ataupun memulai bercocok tanam, kegiatan didahului dengan upacara leka dana dengan memotong ayam yang disertai pembacaan ayat-ayat suci Alquran oleh pemuka agama setempat. Demikian juga ketika membangun permukiman, kegiatan akan diawali dengan memilih lokasi yang ideal, termasuk menguji aroma tanah. Ketika menggali tanah untuk memasang fondasi bangunan, lebih-lebih ruka wanga (rumah bangsawan), kegiatan juga diawali dengan upacara dan penanaman berbagai unsur logam dengan tujuan penyatuan jiwa alam dan pemiliknya, tentu saja diselesaikan dengan pelantunan ayat-ayat suci Alquran.

\section{SIMPULAN}

Kearifan permukiman kuno di kawasan situs Doro Bata dalam skala makro dapat dilihat dari pemanfaatan lokasi permukiman dengan mempertimbangkan aspek bentuk lahan, bentuk permukaan lahan, ketersediaan sumber air dan kesuburan tanah, pencahayaan sinar matahari, dan sirkulasi udara. Kearifan ini berpengaruh terhadap rezeki, kesehatan, dan keharmonisan penghuninya. Secara meso, berdasarkan pengamatan struktur fondasi bangunan dan tangga masuk, bangunan di bidang datar puncak Doro Bata dibangun searah dengan gunung, dan menghadap ke barat. Doro Bata diduga sebagai zona inti, kemudian didukung oleh zona ruang terbuka, permukiman, hutan, bercocok tanam, dan pemakaman. Kearifan disebut lekadana, merupakan warisan pemilihan tempat permukiman ketika ncuhi dahulu sebagai pimpinan masyarakat sebelum Dompu mendapatkan pengaruh budaya Hindu dan Islam. Secara mikro berdasarkan pengamatan pada beberapa bangunan bangsawan Dompu yang masih lestari disebut ruka wanga, ternyata bangunan ini merupakan simbolis kepribadian penghuninya dan dapat menciptakan keharmonisan serta menghindarkan dari pandemi. 


\section{DAFTAR PUSTAKA}

Ambarawati. (2010). Arsitektur Bangunan Hindu di Dompu Perbandingannya dengan Bangunan Hindu di Jawa. Forum Arkeologi, 23(1), 108-121.

Artanegara. (2019). Bekas Istana Raja Dompu. Diambil 8 Februari 2020, dari Indonesiana Platform Kebudayaan website: https://kebudayaan.kemdikbud.go.id/bpcbbali/bekas-istana-raja-dompu/

Atmodjo, M. M. S. K. (1994). Beberapa Temuan Prasasti Baru di Indonesia. Berkala Arkeologi, 14(Edisi Khusus), 1-5.

Bagus, A. G. (2014). Keramik Situs So Langgodu, Dompu: Indikasi Permukiman Masa Lalu. Forum Arkeologi, 27(2), 89-98.

Chambert-Loir, H. (1985). Cerita Asal Bangsa Jin dan Segala Dewa-Dewa. Bandung: Angkasa.

Djafar, H. (2012). Pengaruh Hindu-Buddha di Nusantara Lainnya: Daerah Bima. In E. H. D. Sedyawati (Ed.), Indonesia dalam Arus Sejarah: Kerajaan Hindu Buddha (hal. 57-58). Jakarta: PT. Ichtiar Baru Van Hoeve atas Kerjasama dengan Kementerian Pendidikan dan Kebudayaan.

Haribuana, I. P. Y. (2017). Situs Doro Bente pada Bekas Kerucut Sinder Peti-Tabeh: Koridor Baru Penelusuran Jejak Kerajaan yang Hilang. Forum Arkeologi, 30(1), $11-20$.

Iswati, T. Y. (2003). Tipologi Ruang dalam Rumah-Rumah di Kampung Kudusan Kota Gede. Jurnal Arsitektur, 1(2), 123-134.

Juliawati, N. P. E., Wibisono, S. C., Utami, L. S., Hidayah, A. R., \& Rema, I. N. (2019). Aktivitas Masa Lalu Masyarakat Pendukung Situs Doro Mpana, Dompu. Amerta, 37(2), 139-149. https://doi.org/10.24832/amt.v37i2.139-149

Kusumawati, A. (2007). Local Genius Pada Bangunan Dorobata, Kabupaten Dompu, NTB. Forum Arkeologi, 20(1), 94-115.

Kusumawati, A. (2010). Budaya Austronesia di Dompu Arti dan Maknanya. Forum Arkeologi, 23(3), 511-532.

Mahaviranata, P. (2004). Budaya Kubur Prasejarah Desa HU'U, Dompu, NTB. Forum Arkeologi, 17(1), 1-14.

Muljana, S. (2006). Tafsir Sejarah Nagara Kretagama. Yogyakarta: PT. LKIS Pelangi Aksara.

Pangeran, M. K. (2013). Dari Kontrak Panjang Hingga Musnahnya Istana dari Rakyat: Kisah Sultan Muhammad Siradjuddin Menentang Kompeni. Bogor: CV. Morinawa.

Purwasito, A. (2002). Imajeri India, Studi Tanda dalam Wacana. Surakarta: Pustaka Cakra.

Raffles, T. S. (2014). The History of Java. Jakarta: Narasi.

Rema, I. N., Bagus, A. G., Suarbhawa, I. G. M., Hidayah, A. R., Syafrudin, Nurhaidah, \& Abubakar. (2019). Pola Ruang Istana Dompu: Studi Kasus Kawasan Situs Doro 
Bata. Laporan Penelitian Arkeologi. Denpasar.

Rema, I. N., Juliawati, N. P., \& Prihatmoko, H. (2018). Doro Bata Site in Dompu, Nusa Tenggara Barat: Study Form, Space, and Time. Kapata Arkeologi, 14(1), 79-88.

Rema, I. N., \& Sumerata, I. W. (2016). Penelitian Situs Dorobata Kelurahan Kandai I, Kecamatan Dompu, Kabupaten Dompu, Nusa Tenggara Barat. Denpasar.

Rema, I. N., \& Syafrudin, N. (2019). Pendekatan Ekologi Dalam Permukiman Kuno Situs Doro Manto. Forum Arkeologi, 32(1), 25. https://doi.org/10.24832/fa.v32i1.557

Rossi. (1982). The Architecture of The City. Cambridge Mas: MIT Press.

Saleh, I. M. (1985). Sekitar Kerajaan Dompu, Dompu-Nusa Tenggara Barat. BP7 Kabupaten Dompu.

Sjamsuddin, H. (2015). Memori Pulau Sumbawa. Yogyakarta: Ombak.

Steward, J. H. (1963). Theory of Culture Change (4 ed.). University of Illionis, Urbana.

Suantika, I. W., Ambarawati, A., \& Mahaviranata, P. (1994). Ekskavasi Arkeologi di Situs Doro Bata, Dompu, Nusa Tenggara Barat (Tahap III). Laporan Penelitian Arkeologi. Denpasar.

Sumerata, I. W. (2014). Jejak Peradaban Islam di Situs Doro Bata, Kabupaten Dompu, Nusa Tenggara Barat. Forum Arkeologi, 27(3), 229-238.

Susetyo, S. (2014). Pengaruh peradaban majapahit di kabupaten bima dan dompu. Forum Arkeologi, 27, 121-134.

Syafrudin. (2016). Pola Ruang Pemukiman Berbasis Budaya Lokal Dompu di Desa Hu'u Doтри. Dompu: Bappeda dan Litbang Kab. Dompu.

Tajib, A. (1995). Sejarah Bima Dana Mbojo. Jakarta: PT Harapan Masa (PGRI).

Utomo, B. B. (2018). Peradaban di Pulau Sumbawa pada Abad ke- 7-19 Masehi, Makalah yang disampaikan "Focus Group Discussion Penelitian Arkeologi Doro Bata” di Dompu pada tanggal 17-19 April 2018. Dompu. 
PURBAWIDYA: $\square$ Vol 9, No. 2, November 2020: 149-164 